\title{
Simulation models to study development of the coal industry as energy sector component
}

\author{
Liudmila Takaishvili*, Melentiev Energy Systems Institute of Siberian Branch of the \\ Russian Academy of Sciences, Irkutsk, Russia
}

\begin{abstract}
This paper presents simulation models constructed at Melentiev Energy Systems Institute of SB RAS to study prospects of the coal industry development in Russia and its regions. The models are implemented within the information and model software COAL, which includes four types of models: three types of balance models and a model intended to assess investment projects of enterprises and their groups. The balance models differ in the level of detail of representing the coal industry in regions. The presented models may be applied both jointly with the existing optimization models and independently.
\end{abstract}

\section{Introduction}

A computing experiment in the study of the development of the coal industry as an energy sector component is labor-consuming and weakly formalized, which is explained by the peculiar properties of the coal industry as a research object $[1,2]$. The key properties of the coal industry as a large energy system are: structural complexity, scale, and sluggishness [3-5]. Coal products are characterized by the heterogeneity, usage variety, weak interchangeability and demand. All the above properties are reflected in the models intended to study the coal industry development and operation. In a computing experiment, foreign and Russian researchers apply optimization and simulation models [6-9]. There are models to study both separate processes related to technologies of coal production and processing, and models to study development of coal-mining enterprises, regions, and the whole industry in interaction with other branches of the economy. The Russian experience in modeling the coal industry development totals above 70 years [10-14]. The studies and forecasting of the coal industry development in the country and its regions are carried out at Melentiev Energy Systems Institute on the basis of optimization and simulation models for more than 40 years $[13,14]$.

\section{Information and model software COAL}

To study the coal industry development within the energy sector, the information base and a system of the interconnected models were integrated into the information and model software COAL (IMS COAL) at Melentiev Energy Systems Institute [15]. The IMS COAL comprises: the information system COAL, conditions and limitations for the long run, and a

* Corresponding author: luci@isem.irk.ru 
system of models. Three types of applied models: simulation, calculation, and productiontransportation are formulated in the form of linear programming problems [14]. The presented models may be used both jointly and each independently, depending on the problem statement. One model can be applied to solve several problems. The federation entities (FEs), federal districts (FDs), Russia as a whole, or other territorial entities united by this or that criterion are considered in the models as a coal production and consumption region.

The studies of the prospects for the coal industry development within the energy sector include the following problems to be solved:

1. Analysis of the coal industry state.

2. Generation of scenarios for the economy development (in the country or region).

3. Forecast of the demand for electric and thermal energy and the demand for fuel in the context of the accepted scenario.

4. Forecast of the demanded coal production, and the volumes and directions of coal delivery based on the formed conditions and limitations for the long run.

Problems 1 and 4 are solved by the IMS COAL.

The analysis of the coal industry state involves an analysis of the retrospective dynamics of coal production, consumption and deliveries, the existing state of the resource base in the industry, the policy documents, and the investment projects.

Problems 2 and 3 are solved by specialists in the corresponding fields.

Problem 4 is solved based on the analysis of the industry state and the results of solving Problems 2 and 3.

The results obtained by the optimization models can be finalized using the simulation models, where the expert's knowledge is a defining factor. In this case it becomes possible to consider most of the features determining the coal industry operation.

\section{Simulation models}

\subsection{Characteristics of the models}

The following 4 types of simulation models corresponding to different levels and aspects of study: INVEST COAL, BALANCES, BALANCES OF REGIONS and FEDERARION ENTITY are applied to study the coal industry development.

The models BALANCES, BALANCES OF REGIONS and FEDERARION ENTITY differ in the level of detail of the object representation and in some other aspects. The models of the same type differ depending on the available information and objectives of studies (Table 1). Relations among the market entities are presented by the volumes of coal supplies to the internal (coal-mining region) and external (coal-consuming regions including export) markets.

The simulation models BALANCES, BALANCES OF REGIONS and FEDERARION ENTITY comprise the following main indicators:

- forecast of coal demand;

- forecast of limitations on steam coal reserves;

- forecast of limitations on steam and coking coal production;

- authors' estimates for possible development of regional coal-mining enterprises;

- qualitative characteristics of coals;

- technical and economic indicators of enterprise operation;

- existing scheme for deliveries. 
Table 1. Characteristics of simulation models

\begin{tabular}{|c|c|c|c|}
\hline Model & Level of detail & $\begin{array}{c}\text { Coal market } \\
\text { entities }\end{array}$ & Result \\
\hline BALANCES & Coals, FD & $\begin{array}{c}\text { Groups of } \\
\text { enterprises* }\end{array}$ & $\begin{array}{c}\text { Forecast of demanded coal } \\
\text { production and delivery in } \\
\text { the country and FD }\end{array}$ \\
\hline $\begin{array}{c}\text { BALANCES OF } \\
\text { REGIONS }\end{array}$ & $\begin{array}{c}\text { Coals, FEs, coal- } \\
\text { mining enterprises, } \\
\text { deliveries, export }\end{array}$ & $\begin{array}{c}\text { Consumers: FDs, } \\
\text { export }\end{array}$ & $\begin{array}{c}\text { Forecast of demanded coal } \\
\text { production, schemes and } \\
\text { volumes of coal supply, and } \\
\text { coal balances for FEs and } \\
\text { FDs }\end{array}$ \\
\hline $\begin{array}{c}\text { FEDERARION } \\
\text { ENTITY }\end{array}$ & $\begin{array}{c}\text { Enterprises, coal- } \\
\text { washing plants, } \\
\text { marketable } \\
\text { products, FD areas }\end{array}$ & $\begin{array}{c}\text { Coal-mining } \\
\text { enterprises }\end{array}$ & $\begin{array}{c}\text { Forecast of demanded coal } \\
\text { production and processing in } \\
\text { FEs, coal deliveries to RF } \\
\text { regions, and coal balances in } \\
\text { FEs }\end{array}$ \\
\hline $\begin{array}{c}\text { INVEST COAL } \\
\text { 2) Invect problem }\end{array}$ & $\begin{array}{c}\text { Enterprise or group } \\
\text { of enterprises }\end{array}$ & $\begin{array}{c}\text { Technical and } \\
\text { economic } \\
\text { indicators of the } \\
\text { project }\end{array}$ & $\begin{array}{c}\text { 1) Efficiency indicators } \\
\text { 2) Coal price or other } \\
\text { indicators }\end{array}$ \\
\hline
\end{tabular}

* Groups of enterprises mining coal of certain deposits, or a group of deposits. For example, "Kansk-Achinsky" stands for the coal of the Kansk-Achinsk basin.

The calculation results by the models are presented (with a different level of detail for different models) by enterprise and in aggregate in accordance with the administrative division of the country and regions:

- potentialities for the development of coal mining and possible volumes of export-quality coal production;

- volumes and directions of coal supplies, including those for export;

- volumes of demanded coal mining, including those by enterprise;

- coal reserves to the energy sector;

- commissioning of new capacities in the coal industry;

- volumes of coal processing;

- output of marketable coal products;

- balances of coal on the whole and steam coal in particular;

- demand for resources: capital investment to the coal industry development, employment in coal production and processing, electric and thermal energy for coal production and processing;

- trends in the coal industry development (new construction, capacity expansion);

- structure of mining (surface and underground mining, brown and hard coal, steam and coking coal) and processing;

- tables and plots for inserting into the printed matter.

The model BALANCES is applied to forecast the demanded volumes of coal production and delivery and obtain the diagrams illustrating this forecast for the country based on the data about the potentialities of coal production and demands in the federal districts.

The model BALANCES OF REGIONS is a supplement to the optimization model COAL TRANS and to the model BALANCES. The solution obtained by the model COAL TRANS, and the coal balances for the country obtained by the model BALANCES may be used as a version for coal delivery by region, which is a starting point for searching for the solution. The model BALANCES OF REGIONS is used to study the development of East Siberia and the Far East at the level of the given regions with detail by federation entity and 
coal-mining enterprise. Coal delivery and consumption are forecasted based on the existing trends in coal deliveries and consumption in FEs.

The model FEDERATION ENTITY is intended to study the coal industry development at the FE level. It presents the indicators in the greatest detail: by coal-mining enterprise, coal-washing plant, consumption of certain coals within FE and considering the FE division by any criteria (administrative, transport accessibility and others), etc.

The model INVEST COAL is applied to assess the economic efficiency of the operation and progress of an enterprise or a group of enterprises. It can be used to solve the inverse problem as well: to determine the coal price or other indicators for the set efficiency indicators.

This model allows the calculation of: balance profit, net profit, product profitability and cash flow: proceeds from product sales. The volumes of coal production are determined considering the stripping ratio and volume. The coal production cost includes costs on electric and thermal energy, materials, labor remuneration, depreciation, taxes, payment of loan interest and other costs. The criterion indicators are: current account state, discounted cash flow, net present value, profitability index, product profitability, internal rate of return and payback period. Solution of the inverse problem The price or other indicators are determined as a result of solving the inverse problems at the specified criterion indicator.

Reliability of the obtained estimates can be improved by the analysis of solution stability, which implies the calculation of the dependence of generalizing financial and economic indicators on any changes in the initial parameters of the project (price, investment volumes, etc.).

\subsection{Structure of the models}

The models BALANCES, BALANCES OF REGIONS and FEDERATION ENTITY comprise three functional blocks: PRODUCTION, CONSUMPTION and "COAL BALANCES. A scheme for marketable product calculation and distribution is used in the blocks PRODUCTION and CONSUMPTION.

\subsubsection{Block PRODUCTION}

The output data in this block are the volumes of the obtained marketable products. They are structured by the following attributes: the volumes of coal production at mines, surface mines, operating enterprises, new enterprises; coal production by coal market entity; coal production by sort: brown, hard (steam, coking); marketable products (coking coal concentrate, steam coal concentrate, mid-coal, waste); run-of-mine brown and hard coal production. It is possible to structure the information by other attributes, for example, by groups of enterprises selected in accordance with territorial or administrative division.

The input data are structured in accordance with the coal market entities. Besides, they contain: volumes of coal production presumably delivered to coal-washing plants, ratios between the output of marketable products and waste at the plants.

The marketable products are transmitted to the block CONSUMPTION. The marketable products include the resources for the energy sector, by-product coke plants and export. The marketable products of the steam coal comprise the products of coal processing at coalwashing plants (steam coal concentrate and mid-coal) and run-of-mine (brown and hard) coal production that is supplied to consumers from new and operating enterprises. The export resources are presented basically by steam and coking coal concentrates.

To transmit the steam coal reserves to the block CONSUMPTION, the data in tons are converted into tons of coal equivalent (tce). 


\subsubsection{Block CONSUMPTION}

Coal consumption involves internal coal consumption for the addressed region, coal demand in other RF regions and in the coal-importing countries. The consumers in the RF regions are combined by group: consumers of steam (energy facilities and others) and coking (steel works) coal. The consumers of steam coal are clustered by coal usage: power plants, boiler plants, household and other consumers [2].

The block CONSUMPTION block takes into consideration the demand in obligatory deliveries to energy facilities. Coal-fired power plants are designed for the coal of a certain quality (design fuel).

\subsubsection{Block COAL BALANCES}

The coal balances are calculated on the basis of the demanded coal production and delivery subject to a certain criterion of coal market entity development. The steam and coking coal balances are reduced to the common coal balance.

Calculation of coal balances is an iterative process. The difference between the accessible coal reserves and the demand is determined at the first stage in the Coal balances block. Depending on the obtained results, one or several following actions are possible:

1. The demand exceeds the coal reserves:

a) analysis of possibilities to increase the capacities of the existing operating enterprises or to put new capacities into operation;

b) analysis of possibilities to reduce export deliveries and deliveries to other regions;

c) analysis of possibilities to meet the demand by import from other regions;

d) advice to experts to reduce the coal demand at objects (for example, to shift the commisioning time of new energy capacities).

2. The steam coal reserves exceed the steam coal demand:

a) reduction of coal processing;

b) reduction of coal production;

c) shift of commisioning of new coal production capacities for a later period.

Besides the presented analysis, it is also needed to analyze the compliance between the demand for certain coal and the production possibilities (output of a marketable product) for this coal, because there is practically no interchangeable coal at energy facilities.

At the next stage, the coal industry development conditions are corrected in the block PRODUCTION or CONSUMPTION, and further the solution is obtained iteratively.

As far as the process of study is weakly formalized, an expert may offer other actions, depending on a particular subject of study, which may be represented by any level of the country's administrative division.

\section{Implementation of simulation models}

The simulation models are implemented in MS Excel spreadsheets, which provide the following advantages:

- possibility to easily adjust and adapt the models for a particular study, enter the algorithms for calculation of indicators, compile the tables of results, etc. in accordance with the researcher's requirements;

- possibility to process and represent the calculation results as tables and plots suitable for inserting into the printed matter (papers, monographs, reports), which essentially saves the time of its preparation;

- possibility to make the calculations required during the study. 
Implementations of the balance contain the calculation blocks, economic and mathematical statements of the problem and the reference information.

The economic and mathematical statement of the problem in the model FEDERATION ENTITY provides for:

- territory zoning;

- coal production: brown, hard, coking;

- processing at the coal-washing plants;

- coal deliveries inside the federation entity and to other regions of Russia depending on the coal usage and for export.

In particular cases, individual components may be omitted.

At the beginning of the study, as a rule, there is an uncertainty in the set of available input data, their amount and algorithm for preliminary calculations of the indicators. Implementation of the simulation models in MS Excel spreadsheets makes it possible to perform the routine procedures of calculating the indicators necessary for the study. The input information available by the beginning of the study and uniqueness of the coal industry objects do not allow the software with a fixed input and output to be created for simulation models. The scientific study specificity is that practically each study required its simulation models to be constructed on the basis of the earlier ones depending on the problem statement and other factors. The models are adjusted and updated for each particular study.

The existing uncertainty in the input information both on the potential coal production and the forecast of coal consumption can be eliminated by the scenario approach. The models allow the solution to be found and the resultant tables to be complied for several possible scenarios of the regional and national economy development.

\section{Experience of using the simulation models}

The presented models were applied in different years to forecast the coal industry development in regions and assess the investment projects.

The model INVEST COAL was used to solve the direct and inverse problems for individual enterprises or a group of coal-mining enterprises: Mugunsky, Kharanorsky, Solntsevsky surface mines, VOSTSIBUGOL company, etc. The approach universality made it possible to adapt this model to study other energy objects: coal- and gas-fired condensing power plants; the Vilyui and Boguchany hydro power plants, and others.

The models BALANCES and BALANCES OF REGIONS were applied to forecast the coal industry development for differed scenarios of economy and energy development, and for different time horizons. The forecasts were made for Russia as a whole, for regions (federal districts and federation entities), for coal (production, delivery, reserves, etc.), for coal-mining enterprises. The model BALANCES OF REGIONS is aimed mainly at the coal industry of East Siberia and the Far East for federation entities and coal-mining enterprises.

The studies on the coal industry in Irkutsk and Amur Regions, Sakha Republic (Yakutia), and other federation entities were carried out on the model FEDERATION ENTITY.

Comparison of the results of the studies for many years (2004-2014) with real indicators for the coal industry development over the subsequent years showed that the application of such models to study the prospects for the coal industry development in regions was feasible. The models presented in the paper are sufficiently flexible, adjustable to specific problems, and they are an adequate tool to study the coal industry development. The selected implementation method is rational, which was confirmed by numerous studies. 


\section{Acknowledgements}

This study was carried out within Scientific Project XI.174.2. of the Fundamental Research Program of SB RAS, reg. No. AAAA-A17-117030310435-0.

\section{References}

1. L.A. Melentiev. Systems studies in energy. M.: Nauka, 455 p. (1983) (in Russian)

2. L.N. Takaishvili. Features of the coal industry as a research object within the energy sector // Information and mathematical technologies in science and management: 13th Baikal All-Russia Conf., Irkutsk, July 7-17, 2008. ISEM SO RAN. P. 313-320. (2008) (in Russian)

3. L.N. Takaishvili Features of the computing experiment to study the development of the coal industry within the energy sector // State-of-the-art technologies. System analysis. Modeling. Irkutsk: Irkutsk State Transport University. Special issue, pp. 64-69. (2008) (in Russian)

4. System studies in energy in a new social and economic environment / V.P. Bulatov, N.I. Voropai, A.Z. Gamm, et al. Novosibirsk: Nauka, Siberian Publishers of RAS, 189 p. (1995) (in Russian)

5. Theoretical grounds of system studies in energy / A.Z. Gamm. A.A. Makarov, B.G. Saneev, et al. Novosibirsk: Nauka, 334 p. (1986) (in Russian)

6. Assumptions to the Annual Energy Outlook 2015/ U.S. Energy Information Administration. September 2015. - 224 p. Retrieved from: https://www.eia.gov/outlooks/aeo/assumptions/ (2018)

7. Steve Mohr, Mikael Höök, Gavin Mudd, Geoffrey Evans. Projection of Australian coal production - Comparisons of four models/ Paper presented at International Pittsburgh Coal Conference 2011. Retrieved from: $<$ https://www.researchgate.net/publication/286295507_Projection_of_Australian_coal_ production_-_Comparisons_of_four_models $>/$. (2018)

8. Wojciech Suwala. Modelling adaptation of the coal industry to sustainability conditions Energy, Volume 33, Issue 7, July 2008. P. 1015-1026. Retrieved from: https://ideas.repec.org/a/eee/energy/v33y2008i7p1015-1026.html (22.06.2018)

9. M.D. Budeba, J.W. Joubert, R.C.W. Webber-Youngman. A proposed approach for modelling competitiveness of new surface coal mines / Journal of the Southern African Institute of Mining and Metallurgy (Online). P. 1057-1064. Retrieved from: http://www.saimm.co.za/Journal/v115n11p1057.pdf (2015)

10. N.I. Tsvetkov. Application of the mathematical modeling method to integrated designing of a coal basin. Coal, No. 2, pp. 10-15, (1967) (in Russian)

11. L.S. Plakitkina. Simulation models for coal industry forecasting. Proceedings of RAS. Power Engineering, No. 3, pp. 162-175 (2010) (in Russian)

12. V.N. Churashev, V.M. Markova. Development and transformation of modeling industrial subsystems of FEC: evolution, hierarchy, trends, scenario conditions // System modeling and analysis of meso- and microeconomic objects / Ed. by V.V. Kuleshov, N.I. Suslov; Russian Academy of Sciences, Siberian Branch, Institute of Economics and Industrial Engineering, Siberian Branch of the Russian Academy of Sciences. Novosibirsk, Ch. 3.1, pp. 112-115 (2014) (in Russian)

13. G.V. Agafonov, A.A. Makarov, B.G. Saneev, and A.D. Sokolov. Methods and models for optimizing the coal industry development // Methods for study and management of energy systems. Novosibirsk: Nauka, pp. 330-350 (1987) (in Russian) 
14. G.V. Agafonov, A.D. Sokolov, L.N. Takaishvili. Modeling of coal industry development. Proceedings of RAS, Power engineering journal, No.6, pp. 159-165 (2011), (in Russian)

15. A.D. Sokolov, L.N. Takaishvili. Implementation of the software to forecast coal industry development in Russia's regions. State-of-the-art technologies, System analysis. Modeling, No. 1(41), pp. 126-133 (2014) (in Russian) 